OPEN ACCESS

Edited by:

Michel Prudent

Transfusion Interrégionale

CRS SA, Switzerland

Reviewed by:

Coen Maas,

University Medical Center

Utrecht, Netherlands

Dirk De Korte,

Sanquin, Netherlands

*Correspondence:

Thierry Burnouf

thburnouf@gmail.com

Specialty section:

This article was submitted

to Hematology,

a section of the journal

Frontiers in Medicine

Received: 02 November 2017

Accepted: 30 January 2018

Published: 23 February 2018

Citation:

Drew VJ, Tseng C-L, Seghatchian J and Burnouf $T$ (2018) Reflections on

Dry Eye Syndrome Treatment:

Therapeutic Role

of Blood Products.

Front. Med. 5:33.

doi: 10.3389/fmed.2018.00033

\section{Reflections on Dry Eye Syndrome Treatment: Therapeutic Role of Blood Products}

\author{
Victor J. Drew ${ }^{1,2}$, Ching-Li Tseng ${ }^{1,2}$, Jerard Seghatchian ${ }^{3}$ and Thierry Burnouf ${ }^{1,2 *}$ \\ ${ }^{1}$ International PhD Program of Biomedical Engineering, College of Biomedical Engineering, Taipei Medical University, Taipei, \\ Taiwan, ${ }^{2}$ College of Biomedical Engineering, Graduate Institute of Biomedical Materials and Tissue Engineering, Taipei \\ Medical University, Taipei, Taiwan, ${ }^{3}$ Independent Researcher, London, United Kingdom
}

Dry eye syndrome (DES) is a multifactorial, frequent, pathology characterized by deficient tear production or increased evaporation of tears and associated with ocular surface alteration and inflammation. It mostly affects, but not exclusively, older individuals and leads to varying degrees of discomfort and decreased quality of life. Although the typical treatments of DES rely on using artificial tears, polyunsaturated fatty acids, integrin antagonists, anti-inflammatory agents, or on performing punctal occlusion, recently, standardized blood-derived serum eye drops (SED) are generating much interest as a new physiological treatment option. The scientific rationale in using SED for treating or releasing the symptoms of DES is thought to lie in its composition in multiple factors that resembles that of tears and contributes to the healing and protection of the ocular surface. This manuscript seeks to provide relevant background information on the management of DES, and on the increasing role that various types of SED or platelet lysates, from autologous or allogeneic origins, are playing in the improved therapeutic management of this pathology. The increasing role played by blood establishments in producing better-standardized SED is also addressed.

Keywords: dry eye syndrome, keratoconjunctivitis, artificial tears, serum eye drop, platelet lysate, blood

\section{DRY EYE SYNDROME (DES): EPIDEMIOLOGY, PATHOLOGY, AND SOCIO-ECONOMIC IMPACTS}

\section{Epidemiology}

Dry eye syndrome, also known as dry eye disease or keratoconjunctivitis sicca (KCS), is among the most common ocular complaints that older patients seek eye care for (1). Often under-recognized, DES is a multifactorial disease associated with varying degrees of discomfort and decreased quality of life (2). Awareness of DES varies much among populations, largely influenced by criteria used for self-diagnosis. For instance, in a survey conducted in Japan, 33\% of participants estimated to be affected by DES (3). DES prevalence increases with age. One study found that there are no significant differences in DES prevalence in men of differing races or regions in the United States (1). Females of all age groups have a greater likelihood of developing DES than males, with DES prevalence increasing with age (4). Schaumberg et al. estimate that, in the United States, 1.68 million men over the age of 50 years experience DES and this number is expected to grow to 2.79 million by 2030 
as life expectancy increases (1), whereas a previous health study found that over 3.23 million women are currently suffering from DES (4).

In another study, it was extrapolated that 4.3 million people over 65 years in the United States suffer from ocular irritation at least occasionally (5).

\section{Pathology}

Dry eye syndrome pathology is typically divided into two types: deficient tear production or the evaporation of tears. Deficiency in tear production can be further divided into two more categories: Sjögren's syndrome (SS), which is an autoimmune disease, or non-Sjögren's syndrome (non-SS) (2, 6-8). Evaporation of tears refers to the loss of water from the ocular surface and is often the result of a meibomian gland dysfunction leading to a lipid bilayer deficiency in the tear film. The meibomian gland loses its function with age, leading to tear film instability and evaporation of tears; the quality and function of the meibomian gland has been linked, at least in part, to androgen levels (9). As males have higher androgen levels than females, this is consistent with the higher frequency of DES in females, especially after menopause.

Deficiency of tears caused by the decrease of aqueous tear production or excessive tear evaporation could increase osmolarity, with deleterious effects on the ocular surface. DES is associated with inflammation, and tear hyperosmolarity is an important mediator of this inflammation (2). Hyperosmolarity is associated with a key pathogenic mechanism of DES with negative effects on epithelial cells, including decreased cell volume, damage to DNA repair systems, increased apoptosis, and increased oxidative stress (2). It also stimulates multiple inflammatory events involving metalloproteinase-9 (MMP-9), tumor necrosis factoralpha (TNF- $\alpha$ ), and mitogen-activated protein kinase (MAPK) (2). Indeed, overexpression of proinflammatory cytokines/ chemokines on the ocular surface has been found to be associated with the symptoms of dry eye (10-12), including interleukin (IL)-1 $\beta$, IL-6, IL-17, IL-22, interferon- $\gamma$, tumor necrosis factor $\alpha$ (TNF- $\alpha$ ), chemokine (C-Cmotif) ligand 2 (CCL2), and matrix metalloproteinases $(13,14)$.

In addition to dryness, symptoms associated with DES include pain, burning sensations, eye fatigue, redness, blurred vision, discharge, contact lens intolerance, sensitivity to light, and the feeling of foreign bodies present in the ocular region (2). Depending on the severity of DES, some patients experience problems carrying out basic daily activities such as reading, watching television, using a computer, driving a vehicle, and working (15). The discomfort caused by DES has also been tied to depression and decreased quality of life (2, 16-18). Furthermore, one study conducted a battery of tests, including tear function and ocular surface evaluations, and questionnaires on DES patients and determined a correlation between lower DES symptoms and patient happiness, suggesting that DES may influence a patient's psychiatric well-being (19). A study of depression in DES subjects identified that these patients experience poor sleep quality (16). DES patients tend to sleep later, less, and use more sleep medications and antidepressants than non-affected subjects.
However, antidepressants are being investigated as a potential contributor to DES (20), and patients with severe DES that progressively worsens over time suffer from increased anxiety and other mood disorders $(2,16)$.

\section{Socio-economic Impacts}

Dry eye syndrome places a substantial economic burden on society due to hospital visits, medical costs, surgeries, and drugs, in addition to indirect costs such as loss of productivity (21). In the United States, the average DES patient makes approximately 6 hospital visits annually at a total cost of nearly \$800 USD, adding up to a national cost of nearly $\$ 4$ billion USD. These costs have risen over the years. When taking loss of productivity into account, annual societal costs are estimated to exceed $\$ 55$ billion in the United States (22). In Europe, the estimated annual cost for ophthalmologist-managed care ranged from approximately $\$ 270$ USD in France to $\$ 1,100$ USD in the United Kingdom (21). In Japan, DES patient annual medical costs amounted to roughly $\$ 470$ USD, mostly for drugs (21). Additionally, loss of work productivity in Japan was calculated to be approximately $\$ 536$ USD per patient $(21,23)$. Surprisingly, the economic burden of DES due to loss of productivity drastically outweighed the direct expenses from receiving care from healthcare professionals or prescription drugs (22). Although the apparent costs vary among countries, the real costs of DES in each country are likely higher than data shows when taking into account that the purchase of over-the-counter artificial tears is not always incorporated into cost calculations (24) and data are incomplete, in particular in some parts of Asia (21).

\section{CURRENT THERAPEUTIC STRATEGIES}

The past 5 years have witnessed substantial developments in DES treatment options. Current treatment strategies that are not based on blood products include artificial tears, lubricants, steroids, immunosuppressant eye drops, dietary supplements associated with eyelid cleansing, and in more extreme case, antiinflammatory drugs or punctal occlusion, a procedure consisting of inserting a plug into the tear drainage area to maintain tears in the eyes. Generally, such treatments, which can be combined, are selected based on disease severity and medical history of the patient. For the majority of DES cases, treatments focus on alleviating symptoms rather than addressing the causes of DES (6-8). Treatment effectiveness on symptoms must be regularly assessed (25). Regular use of artificial tears, anti-inflammatory drops, or punctal plugs provides only transient release and can often induce ocular side effects.

\section{Artificial Tears}

The main functions of artificial tears are to increase moisture and provide lubrication of the ocular surface (26). There is a variety of artificial tear formulations available, differing in osmolarity, viscosity, electrolyte content, preservative content, and solute combinations (27). Artificial tears are currently formulated as osmoprotectants, with the purpose of restoring cell volume, decreasing cell stress, and reducing inflammatory reactions that occur under hyperosmotic conditions (28). One 
eye drop product uses propylene glycol (PG), polyethylene glycol (PEG), and hydroxypropyl guar (HP-Guar) with polyquaternium-1 preservative, which decreased ocular surface inflammation and DES symptom severity (29). Similarly, another eyedrop formulated using hyaluronic acid (HA) and trehalose stabilizes the bilipid membranes and protects labile proteins from desiccation, as well as prevents oxidative damage $(30,31)$.

A recent Cochrane analysis (27) could not identify whether different over-the-counter artificial tears provide "similar relief of signs and symptoms when compared with each other or placebo." However, $0.2 \%$ polyacrylic acid-based artificial tears were found to be more effective than $1.4 \%$ polyvinyl alcohol-based artificial tears. In addition, artificial tears are not free of inducing some adverse events.

One limitation of artificial tears is the lack of some of the components of natural tears such as lipids, salts, proteins, and hydrocarbons, as well as growth factors, immunoglobulins, albumin, and vitamins present in serum, as discussed later $(28,32-34)$. Additional possible drawbacks of artificial tears include the presence of preservatives and other potentially toxic and allergenic compounds (35). Benzalkonium chloride (BAK), the most frequently used preservative compound in eye drops, may contribute to hyperosmolarity by disrupting tear films. BAKinduced damage extends to destruction of goblet cells, the corneal epithelium barrier, and deeper ocular tissues including release of proinflammatory cytokines, oxidative stress, and apoptosis (35). These factors should be taken into consideration when prescribing DES treatments.

\section{Polyunsaturated Fatty Acids (PUFAs)}

Omega 3 and 6 fatty acids are essential fatty acids that cannot be synthesized in the human body. Their improper balance can lead to an omega 6 proinflammatory effect (8). Dietary supplementation of polyunsaturated fatty acids (PUFAs) may help manage DES $(8,36)$. In a randomized, double-blind study, omega-3 supplementation promoted tear film stabilization, reducing tear evaporation and DES symptoms as a result of increased goblet cell counts and improved epithelial cell morphology $(8,36)$. Balanced combination of omega-3 and omega- 6 was recently found to attenuate contact lens-related DES (37).

\section{Integrin Antagonist}

Lymphocyte function-associated antigen-1 (LFA-1), an integrin expressed on T-cells, is upregulated in the conjunctiva of DES patients (38). The interaction between LFA-1 and intercellular adhesion molecule-1 (ICAM-1) is key in T-cell adhesion with endothelial cells, as well as for T-cell interaction with antigen presenting cells (38). One approach to treat DES aimed to block the interaction between LFA-1 and ICAM-1. A small LFA-1 antagonist called Lifitegrast (SAR 1118) demonstrated in phase III clinical trials to significantly and safely relieve DES symptoms (39). Lifitegrast acts as an antagonist to LFA-1, resulting in the inhibition of T-cell activation, migration, and proliferation (40). However, other parameters to assess ocular function, such as Schirmer's test results, tear breakup time, and inferior corneal staining, did not improve significantly (41). In July 2016, Xiidra ${ }^{\circledR}$ was the first United States Food and Drug Administration (US-FDA)-approved LFA-1 agonist for treating DES (40).

\section{Anti-Inflammatory Therapies and Immunomodulators}

Corticosteroids are one among several anti-inflammatory drugs to treat DES. In addition to reducing cellular infiltration, restoring vascular permeability and inhibiting chemotaxis, corticosteroids decrease fibroblast proliferation, reduce capillary dilation and suppress collagen deposition (40). They are considered highly effective toward the treatment of immune-mediated inflammatory diseases (40). However, their efficacy is limited to short-term usage (4 weeks or less) (41) as long term use leads to intraocular pressure and the formation of cataracts $(40,42)$. A combination with anti-inflammation agent (epigallocatechin gallate, EGCG) and mucoadhesive component, hyaluronic acid (HA) was used for the treatment of DES in a rabbit experimental model (43). Its therapeutic effect was evidenced via increased tear production, inflammation relief, and corneal epithelium recovery providing an alternative inflammatory inhibition agent for clinical DES treatment.

Cyclosporine is preferred over corticosteroids as a longterm treatment for DES. Cyclosporine A is a topical immunomodulator, first approved by the FDA in $2002\left(\right.$ Restasis $\left.^{\circledR}\right)$ for treating dry eye by increasing tear production (44) and by the European Union in 2015 (Ikervis $^{\circledR}$ ) (45). When administered topically, cyclosporine A acts as an immunomodulator, and when administered systemically, it acts as an immunosuppressant (8). This drug elicits anti-inflammatory properties by inhibiting cell-mediated reactions and preventing the release of proinflammatory cytokines, while upregulating the production of anti-inflammatory cytokines (44). Multiple studies have reported minimal side effects associated with topical application of cyclosporine $\mathrm{A}$, under conditions increasing tear production and conjunctival goblet cell density $(8,45-47)$.

\section{Punctal Occlusion}

Lacrimal punctal occlusion by plug is the most common non-pharmacological therapy for DES $(48,49)$. Although many authors recommend temporary occlusion by plugs as a trial treatment, permanent occlusion can be achieved through surgical obstruction of the lacrimal punctum. It has been described as being like "blocking the drain in a tub and collecting the water dripping from the tap" (50), which in other words means preventing tear drainage toward the nasal cavity by physically blocking the lacrimal punctum/canaliculus. Punctal occlusion is typically recommended for patients suffering from DES symptoms after failed attempts of using traditional aqueous treatment options (49). Although punctal occlusion may improve DES symptoms, there is a concern that it could retain unhealthy tears on the ocular surface causing irritation (51) and does not decrease tear cytokines and MMP-9 levels (52). An international panel of dry eye specialists recommended that factors associated with inflammation be handled prior to performing punctal occlusion (53). A study comparing the effects of administering punctal 
occlusion alone versus a punctal plug regime in combination with cyclosporine treatment demonstrated that for the near term, punctal occlusion, alone or with cyclosporine, yielded swift improvement in moisture. However, for the long term, treatment regimes involving punctal occlusion in combination with cyclosporine produced equal or superior results to treatment regimes using occlusion plugs only (50). A recent Cochrane study has identified a "very low-certainty evidence on symptomatic improvement" of punctal occlusion, commonly associated with epiphora and inflammatory conditions (54).

\section{BLOOD PRODUCT-BASED DES TREATMENT OPTIONS}

\section{Scientific Rationale}

Human blood has been for many decades the source of a wide range of cell-based or protein-based therapeutic products. Cellular products include red blood cell (erythrocyte) concentrates, buffy coats/granulocytes concentrates, and platelet (thrombocyte) concentrates. Therapeutic proteins encompass coagulation factors, albumin, and immunoglobulins. More recently, new plateletderived preparations, rich in growth factors, have been increasingly used for therapeutic applications in wound healing, tissue repair and regeneration (55), and in vitro clinical-grade cell propagation and tissue engineering (56).

There is now great interest in the application of human blood derived products as eye drops for DES. The most common blood product used as eye drops is serum, which is obtained by a physiological clotting process of blood collected without anticoagulant, as described in details below. The therapeutic benefits of blood-derived serum eye drops (SED) are probably multifactorial and may be explained by a composition that, in part, shares similarities with that of tears (32-34,57). Like tears, SED contains carbohydrates, lipids, and various electrolytes, but 10 times more proteins including albumin, fibronectin, and transferrin (33). SED contains natural antimicrobial components, like complement component (58), and IgG, but less lysozyme than tears (32). Tears and SED provide vitamins and both share a similar osmolality (close to $300 \mathrm{mosm} / \mathrm{l}$ ) as they contain comparable sodium and anion levels, and a similar $\mathrm{pH}$ (close to $\mathrm{pH} 7.4)(33,59,60)$. Potassium ion levels are about five times higher in tears than in SED, but calcium ions and phosphate levels are less in tears than in SED (33). However, the total protein content of tears is only about $10 \%$ that of SED (33). IgA is the major immunoglobulin in tears, playing a role in protecting against infections. Vitamin A is less in tears than in serum. Vitamin $\mathrm{C}$ and glutathione antioxidants are present at higher levels in tears than in serum. Most importantly, SED, like tears (61), also contain a mixture of cell growth promoting agents $(62,63)$, since blood clotting is associated with a degranulation of the platelets and a release of a plethora of growth factors from their alpha-granules $(56,64,65)$. Growth factor composition is said to be qualitatively equivalent in tears and serum, but concentrations may be higher in serum, as is the case for transforming growth factor-beta (TGF- $\beta$ ) and platelet-derived growth factor (PDGF). Table 1 presents some of the known similarities existing between tears and SED.

\section{Serum Eye Drop \\ Preparation}

Serum refers to the fluid portion of blood, devoid of cellular components that is obtained by letting blood collected without an anticoagulant to clot. It is typically prepared by collecting blood from patients (autologous source) or donors (allogeneic source), allowing the blood to clot for several hours prior to a centrifugation step at ca. $3,000 \times g$ for approximately $10 \mathrm{~min}$ at $20-25^{\circ} \mathrm{C}$ to recover a supernatant serum. Serum may be passed through a $0.22-\mu \mathrm{m}$ pore-sized filter for bacterial sterilization and clarification $(34,57,66)$. In such a preparation, the platelets are not concentrated compared to the level found in the blood circulation, by contrast to newer SED formulation made from platelet concentrates where platelets are threefold to fivefold enriched compared to blood. When SED are made from platelet concentrates for transfusion, the content of serum plasma protein depends upon whether the platelets are suspended in 100\% plasma or a mixture of plasma and platelet additive solution (PAS).

An informative survey of methods used at international levels to prepare SED has recently been conducted by the Biomedical Excellence for Safer Transfusion (BEST) Collaborative (67). A summary of the preparation methods of SED is illustrated in Figure 1. Briefly, this survey indicates that SED for clinical use are prepared by national or regional blood establishments (also known as blood centers), as well as by hospitals or medical centers. Although most centers are manufacturing SED of autologous origin, an increasing number is now producing SED from allogeneic blood donors (68-70). When the SED are from allogeneic origins, procedures are in place, e.g., by preparing SED from $\mathrm{AB}$ group donors to hold a single blood group inventory or by donation screening to match all blood groups to ensure hematoimmunological matching between donors and recipients. It is, however, still unknown whether presence of anti-B agglutinins affect corneal healing (67).

A small majority of centers (most likely the blood establishments familiar with the production of blood components for transfusion) prepare SED from blood collected into blood bags rather than into tubes and use larger volumes of $200 \mathrm{~mL}$ or more. While the clotting time to get serum may be less than $6 \mathrm{~h}$, it can be up to $24 \mathrm{~h}$ and (somewhat surprisingly) up to 3 days in some places. Most often, the serum is centrifuged to clarify the supernatant. Most centers do not perform a bacterial filtration step, whereas others do, implying that they apply the standard close-system manufacturing practices familiar to blood establishments. A small majority of the centers dilute the serum twofold to fivefold in saline or phosphate-buffered saline solution, before immediate dispensing in $0.5-5 \mathrm{~mL}$ aliquots into vials/eye dropper bottles or tubing segments before freezing (67).

\section{Formulation}

To date, the optimal formulation and dilution factor of SED for DES treatment remains uncertain. This is not unexpected considering the biological complexity of the serum material compared to artificial tears. Sometimes, the serum is diluted to approach 
TABLE 1 | Comparison of tears and serum composition (individual variations may affect the values).

\begin{tabular}{|c|c|c|c|}
\hline & Tears & Serum & Physiological function possibly relevant in ocular defect treatment \\
\hline \multicolumn{4}{|c|}{ Physico-chemical parameters $(33,57)$} \\
\hline Osmolality, mosm/l & 302 & 300 & Maintains physiological osmolality and pH \\
\hline $\mathrm{pH}$ & $7.2-7.4$ & $7.2-7.4$ & \\
\hline \multicolumn{4}{|l|}{ Proteins $(33,55,56,74)$} \\
\hline Total proteins, mg/mL & 7.37 & $60-70$ & $\begin{array}{l}\text { Support tear surface tension, physiological hydration of the ocular surface, } \\
\text { and ocular homeostasis }\end{array}$ \\
\hline Albumin, mg/mL & 0.05 & $35-40$ & Anti-apoptotic activity, detoxification \\
\hline Fibronectin, $\mu \mathrm{g} / \mathrm{mL}$ & 21 & $200-300$ & Adhesion protein supporting wound healing \\
\hline $\operatorname{lgG}, \mathrm{mg} / \mathrm{mL}$ & 0.032 & $8-12$ & Anti-microbial \\
\hline $\operatorname{lgA}, \mathrm{mg} / \mathrm{mL}$ & 0.41 & & Anti-microbial \\
\hline $\operatorname{lgM}, \mathrm{mg} / \mathrm{mL}$ & - & 0.5 & Endotoxin binding \\
\hline $\operatorname{lgD}, \mu \mathrm{g} / \mathrm{mL}$ & - & $3-300$ & \\
\hline $\operatorname{lgE}, \mu \mathrm{g} / \mathrm{mL}$ & - & $0.25-0.7$ & \\
\hline Alpha 2-macroglobulin & & 2.6 & Anti-collagenase \\
\hline Complement system & & & Anti-microbial; bacteriostatic \\
\hline Lactoferrin, mg/mL & 1.51 & - & Anti-microbial and anti-inflammatory \\
\hline Transferrin, mg/mL & - & $2-3$ & Iron-carrier; anti-microbial \\
\hline Lysozyme, mg/mL & 1.4 & 6 & Iron carrier; anti-microbial \\
\hline \multicolumn{4}{|c|}{ Growth factors $(33,55-57,61)$} \\
\hline TGF- $\beta 1, \mathrm{ng} / \mathrm{mL}$ & $2-10$ & $6-50$ & Epithelial and stromal repair processes \\
\hline PDGF, ng/mL & $0.09-1.7$ & $30-100$ & Enhances mitosis and scarring \\
\hline EGF, ng/mL & $0.2-3$ & $0.5-1$ & Accelerates the migration of epithelial cells; anti-apoptotic \\
\hline HGF, ng/mL & $0.2-0.5$ & $0.1-1$ & Supports corneal epithelial cells \\
\hline VEGF, ng/mL & 0.019 & $1-5$ & Supports conjunctival endothelial permeability \\
\hline \multicolumn{4}{|l|}{ Vitamins (33) } \\
\hline $\mathrm{A}, \mathrm{ng} / \mathrm{mL}$ & $16-20$ & $800-1000$ & $\begin{array}{l}\text { Prevents squamous metaplasia and helps maintain the normal histology } \\
\text { in the conjunctiva }\end{array}$ \\
\hline $\mathrm{C}, \mu \mathrm{g} / \mathrm{mL}$ & 117 & $7-20$ & Antioxidant \\
\hline \multicolumn{4}{|l|}{ Antioxidants (33) } \\
\hline Tyrosine, $\mu \mathrm{M}$ & 45 & 77 & \\
\hline Glutathione, $\mu \mathrm{M}$ & 107 & ND & \\
\hline \multicolumn{4}{|l|}{ Electrolytes (33) } \\
\hline $\mathrm{Na}+, \mathrm{mEq} / \mathrm{L}$ & 145 & $135-146$ & \\
\hline $\mathrm{K}+, \mathrm{mEq} / \mathrm{L}$ & 24.1 & $3.5-5.0$ & \\
\hline $\mathrm{Ca}^{2+}, \mathrm{mM}$ & 1.5 & 1.1 & \\
\hline $\mathrm{Cl}^{-}, \mathrm{mM}$ & 128 & $96-108$ & \\
\hline $\mathrm{HCO}_{3}^{-} \mathrm{mM}$ & 26 & $21-29$ & \\
\hline $\mathrm{NO}_{3}^{-} \mathrm{mM}$ & 0.14 & 0.19 & \\
\hline $\mathrm{PO}_{4}^{3-} \mathrm{mM}$ & 0.22 & 1.42 & \\
\hline $\mathrm{SO}_{4}^{2-} \mathrm{mM}$ & 0.39 & 0.53 & \\
\hline
\end{tabular}

the composition of tears and to decrease the concentration of TGF- $\beta$, which may exert an anti-proliferative activity and impair the healing of epithelial cells (33). There is, nevertheless, no real consensus yet nor evidence-based information on the optimal formulation (71). One cannot exclude that formulation may have to be adjusted to the disease treated or its extent (dryness or epithelium defect). Lower dilution factors (50\%), or even no dilution at all, have been used $(57,72)$, while other authors have proposed to dilute SED to $20 \%$ in a sodium hyaluronate solution in particular to improve retention time and decrease the frequency of the administration (73). Higher SED concentrations have been reported to increase the speed of epithelial healing and closure in a patient recovering from laser in situ keratomileusis (LASIK) eye surgery (66).

\section{Safety Aspects}

Autologous SED do not essentially present risks of extraneous virus contamination when produced under GMP restricting the risks of cross-contamination or mislabeling with SED from another patient. Release testing focusing on microbial sterility of the final batch is carried out by about half of the producers that were recently surveyed (67). Preservative solutions are not added in SED; preparation procedures should therefore be carefully controlled and monitored to prevent bacterial contaminations. 


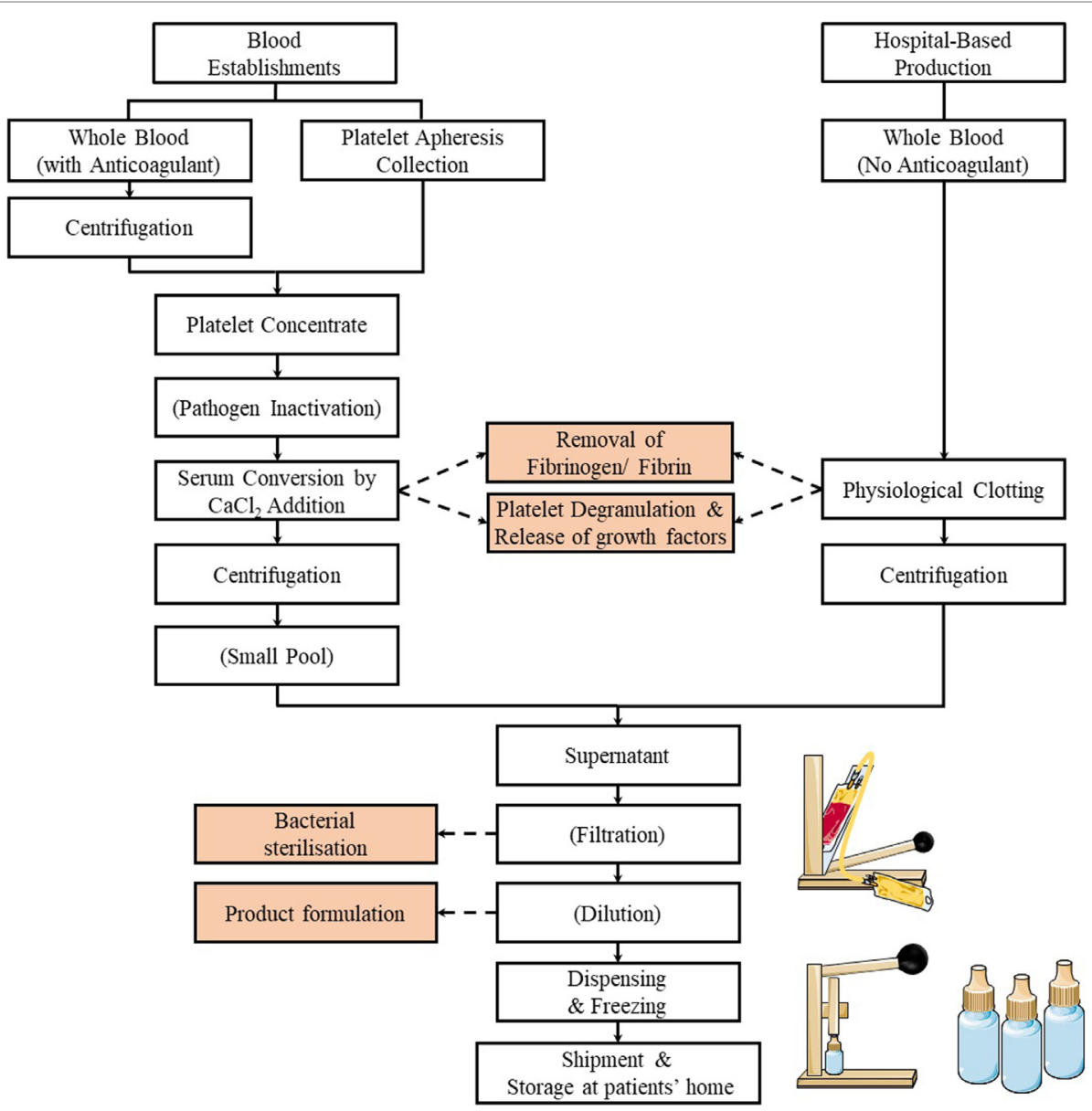

FIGURE 1 | Flowchart of the preparation methods of serum eye drop by blood establishments and hospitals. Typically, the process involves the release of the platelet growth factors by physiological or $\mathrm{CaCl}_{2}$ stimulated clotting of blood (or platelet concentrates), followed by centrifugation, filtration (optional), dilution (optional), dispensing, and freezing.

Allogeneic blood donors donating blood for the production of SED should be screened for virus markers using the same standards that are applied to donations devoted to the manufacturer of transfused blood products $(67,74,75)$. The main transfusion transmitted infections associated with allogeneic serum are viruses, most notably human immunodeficiency virus, and hepatitis B and C viruses (76). Emerging viruses, like West Nile virus, Dengue virus, Chikungunya virus, Ebola virus, and Zika virus, may also be a potential threat (77). However, efficient safety measures in place in blood establishments, namely donors' screening and donation testing, dramatically restrict the risks of viral transmissions in a regulated blood collection jurisdiction (78). Particular future attention may need to address the pathological consequences of risks of transmission of other blood-borne viruses, such as the Herpes simplex virus, that may lead to ocular complications and affect vision (79).

Photochemical pathogen inactivation methods are in use for transfused plasma and platelet concentrates $(80,81)$, but they are not a current option as no dedicated or licensed pathogen inactivation treatment has been approved for application to therapeutic serum, although experimental studies have shown applicability to serum for cell expansion (82). As therapeutic platelet concentrates can be pathogen-inactivated using licensed treatment, this may speed-up the development of allogeneic pathogen-inactivated SED for clinical use (67). The well-established solvent-detergent (S/D) treatment, already applied to a wide range of biopharmaceutical preparations and plasma products (76), was experimentally proven applicable to rabbit SED (83). This S/D-treated rabbit serum was used as allogeneic SED equivalent to treat DESrabbits, showing promising results. The safety and efficacy of such S/D-treated SED was demonstrated through the restoration of a corneal epithelium in a DES rabbit model. This preclinical study supports the possibility of using S/D virally inactivated SED to treat DES for the application of allogeneic human SED (83).

\section{Shipment and Storage}

Most often, patients themselves collect the SED from the production site and store the bottles at home in a domestic freezer. The typical specified shelf life set by producers of SED ranges from 3 to 12 months until thawing and up to $24 \mathrm{~h}$ to 1 week after thawing. Currently, SED storage at patients' home is not specifically controlled and is under patients' responsibility 
$(33,67)$. Studies have suggested that SED can be stored liquid at $4^{\circ} \mathrm{C}$ for up to 1 month, or frozen at $-20^{\circ} \mathrm{C}$ or $-80^{\circ} \mathrm{C}$ for up to 3 to 6 months, and in the dark to limit the decay in vitamin $\mathrm{A}$ $(62,71,72)$. The stability of factors in serum, such as vitamin A, EGF, and TGF- $\beta$, was shown over up to 9 months. However, stability evaluations based on functional or biological activity (e.g., using cell cultures or animal models), rather than immunological tests (e.g., ELISA measurement of growth factors), should be conducted to determine the shelf-life. Furthermore, variations in the preparation methods of SED may impact its quality and properties (57, 72, 84) and, potentially, influence its long-term stability. Topical application of SED, which do not contain preservatives in order to prevent toxicity, requires careful handling to avoid microbial contamination.

\section{Regulations}

The regulatory status of current SED varies, but these preparations are typically regulated as blood products with variations from country to country depending upon jurisdictions (85). The increasing number of blood centers producing SED should eventually lead to the recognition and regulation of SED as a blood product, and to the establishments of international guidelines underlying their manufacture, and efforts towards implementing guidelines for standardization and product specifications. Clinical trials are expected to provide more rigorous information of clinical efficacy in various ocular pathologies and guidance for optimal products' performance and clinical outcomes (67).

\section{Clinical Rationale and Experience}

The clinical strategy behind administering autologous serum is to take a comprehensive approach to treating dry eye, rather than just serve as a lubricant. Recent studies and review papers generally confirm the benefit of SED, from autologous or allogeneic sources, providing improved tear film stability, ocular surface health, and subjective comfort in refractory DES (57, 59, 71, 86-93). According to a Cochrane review based on a limited number of randomized clinical trials, autologous SED alleviate dry eye symptoms better than artificial eye drops for the first couple of weeks, but data still remain inconclusive at determining clinical efficacy over long-term periods (72). Therefore, randomized clinical trials involving larger cohorts of various patient groups should be conducted to better delineate the short-term and longterm benefit of SED in the treatment of DES and other ocular diseases $(26,72,87)$.

\section{Cost Consideration and Reimbursement Policy}

Cost is a major limitation of using autologous SED. In the United States, most health insurance providers do not cover this form of dry eye treatment, resulting in out-of-pocket costs between $\$ 175$ and $\$ 250$ for a 2-month supply. The cost of this treatment may therefore makes it an option to consider for patients who have already exhausted more conventional forms of dry eye treatment.

\section{Pending Issues}

\section{Autologous versus Allogeneic Products}

Currently, there is no universal consensus of criteria on suitable patient selection for autologous blood donation (72). Another disadvantage of using autologous serum is that occasionally the frequent drawing of blood can be inconvenient to patients with prolonged treatment (59). For the elderly and for newborns with serious infections, autologous serum products may be unavailable or contraindicated (94). Cultural considerations are also playing some role. Patients of many Asian cultures, especially the elderly Chinese and Taiwanese, hold the belief that frequent venipuncture causes weakness and makes them more prone to bacterial infection (94). Also some people fear phlebotomy. Additionally, some patients may be too old to donate due to poor venous access or do not possess blood suitable for conversion into autologous SED due to clinical conditions such as previous cerebrovascular accidents, cardiovascular disease, anemia, use of anticoagulant medications or coagulation factor deficiency, or presence of inflammatory mediators $(59,70,92)$. Allogeneic serum consists of the same general substances as those in autologous serum, but from a different source and provides a potential alternative treatment for these patients (59). Allogeneic SED are thus being researched for their efficacy in treating a variety of eye disorders associated with DES including persistent corneal epithelial defect (PED), KCS, chronic graft-versus-host disease (cGVHD), and many more $(69,88,94)$. In other words, some ocular pathologies may actually benefit from SED made from allogeneic source, rather than autologous.

The use of allogeneic SED poses some risks of its own including the transmission of blood-borne pathogens, hypersensitivity and immune reactions, and potential legal or ethical concerns (59). To overcome some of the risks associated with allogeneic serum, some researchers have limited their investigations to SED obtained from family members (69). It has been reported that these eye drops are clinically comparable to autologous serum (94), but obtaining blood from family members does not imply the absence of risks, including infectious one's. A ready-made, ABO-specific allogeneic eye drop study involving 34 patients $(20$ patients with KCS and 14 with PED) observed no side effects in any of the subjects and recorded objective improvement in $59 \%$ of the subjects. Of patients with KCS, relief was reported in $80 \%$ of the patients after allogeneic eye drop treatment (69). In a separate study investigating allogeneic serum in 36 PED patients, the epithelial defect of 16 subjects had healed in 2 weeks time (94). These results were confirmed with the observation of partial or full corneal changes in 16 of the 20 patients. This particular study supports the clinical potential for, and safety of, allogeneic eye drops. However, several immunological and physiological concerns still need to be given due consideration, namely $\mathrm{ABO}$ and HLA antibodies that may initiate inflammation (69). As such the virus safety and immune-hematological screening criteria of blood donations used to make allogeneic SED should be in line with those used for blood components for transfusion.

Due to the risk of transfusion-transmitted infections, it is highly recommended that manufacturers and documenters of allogeneic blood products implement good manufacturing practice as is recommended for the collection of blood components by blood establishments $(67,74,75,85)$.

Newer and Emerging Strategies Using Other Blood Products Various other blood-derived preparations can be considered as therapeutic options to relieve DES symptoms and improve 
patients' quality of life. It was identified, using a dry eye rat model, that plasma albumin provides a therapeutic benefit that was attributed to suppression of apoptosis (95). Albumin added to an eye drop formulation also helps to relieve DES symptoms in a rabbit model (96). Recent trends in development of blood products to treat DES focus on using blood fractions enriched in platelets (therefore equivalent to therefore somewhat equivalent to what is typically known as platelet-rich-plasma or PRP) as source material as the combination of platelet growth factors is believed to provide a scientific rationale to support its healing potential of DES (69). In the above-mentioned international survey (67), four centers manufacture eye drops either from (a) platelet-rich plasma (PRP) from human cords, (b) autologous platelet rich plasma donations, or (c) plasma. There is great interest in producing SED from PRP or platelet concentrate, as this blood fraction contains a threefold to fivefold higher platelet count than does whole blood.

A product termed Eye-PRP ("E-PRP") is prepared by collecting whole blood in the presence of a $3.2 \%$ sodium citrate anticoagulant solution (97) in order to avoid serum formation. Anticoagulated whole blood is centrifuged to sediment red blood cells and to recover a platelet-enriched supernatant plasma. This PRP is then directly divided into aliquots of 3-4 $\mathrm{mL}$ and stored in $4^{\circ} \mathrm{C}$ refrigeration for 1 week or stored in $-20^{\circ} \mathrm{C}$ freezer for extended periods $(97,98)$. Growth factors in E-PRP act to stimulate angiogenesis, promote cell repair, and activate macrophages (97). These essential molecules are actually commonly used in ophthalmology to promote epithelial wound healing of the cornea (98). $89 \%$ of patients using E-PRP eye drops four to six times per day reported subjective absence of DES symptoms. Benefits extended to include increased visual acuity, increased tear production, and improvements in ocular surface condition (98). A similar conclusion was reached by a study investigating the effect of this PRP on human lacrimal function (99).

An alternative to autologous serum and E-PRP is "plasma rich in growth factors" (PRGF). PRGF contains, like serum and E-PRP, a number of platelet growth factors, including plateletderived growth factor, angiopoietin-1 (ANG-1), epidermal growth factor (EGF), VEGF, and many more (100, 101). PRGF can be prepared by collecting $30 \mathrm{~mL}$ of whole blood in tubes containing $3.8 \%$ sodium citrate and centrifuging the tubes, using soft spin, at $460 \times g$ at room temperature for $8 \mathrm{~min}$. The plasma supernatant portion is recovered, and the platelets are activated using $22.8 \mathrm{mM}$ calcium chloride (102). Addition of calcium chloride induces a process of serum-conversion where a fibrin clot is generated, and growth factors are released due to platelet activation and degranulation. Afterward, the growth factor-rich supernatant serum is collected and filtered. It can be diluted with $0.9 \%$ sodium chloride down to $20 \%$. All of these steps are performed under sterile conditions. The final product is distributed into eye drop dispensers, ready for use. For immediate usage, the eye drops could be stored in $4^{\circ} \mathrm{C}$ refrigeration up to 1 week, and for long-term storage, at $-20^{\circ} \mathrm{C}$ for no longer than 3 months. Patients administer eye drop solution four times per day. Treatment cycles last approximately 3 months, but treatment can be extended several more months to include more cycles if symptoms do not improve. A study investigating the efficacy of PRGF to treat DES reported that out of 16 patients, $75 \%$ experienced moderate to substantial improvements. Use of PRGF has demonstrated an ability to reduce symptoms of squamous metaplasia in patients suffering from DES (101).

As mentioned above, the development of human platelet lysates (HPL) manufactured from platelet concentrates collected following the licensed procedures in place to prepare blood products for transfusion is very likely and opens the roadmap for the development of more standardized SED (103).

Finally, recently, a limited case study was conducted in the UK where patients applied a drop of whole blood to the affected eye(s) four times daily for 8 weeks. Significant improvements were noted in several parameters, such as visual acuity, corneal staining, tear break-up time (TBUT), and ocular comfort index (OCI), but not Schirmer's test (104).

\section{CONCLUSION AND FUTURE PROSPECTS}

Dry eye syndrome is a common eye condition with a range of causes and degrees of severity and tremendous socioeconomic implications in addition to reductions in quality of life. There is a wide variety of medical products and procedures currently available or under development for the treatment of DES, each with their own advantages and disadvantages. Emerging treatment options include products derived from whole blood, such as autologous or allogeneic SED, E-PRP, PRGF, and HPL.

Relevant questions regarding the production method, quality, efficacy and safety of blood products used to treat DES remain, as already identified in particular with regards to standardization and formulation $(87,103)$. Similar to most claimed applications of platelet-derived preparations used in regenerative medicine, work is needed to design and standardize SED production methods to yield formulations with optimized blood proteins and growth factors composition to best address various DES and ocular pathologies. Reliable in vitro tests should be identified and validated as predictor of clinical outcomes (87). Furthermore, pre-clinical studies using valid animal models (105) to delineate the respective contribution of the plasma and platelet proteomes in the benefits of blood-derived eye drops in releasing DES symptoms should be performed. As is the case in other fields of regenerative medicine (106), dedicated platelet lysates may be needed to tackle the specific micro-environment of the diseased tissues and promote optimal repair strategies. An increasing involvement of blood establishments in producing SED is expected to contribute to improve standardization, quality, and safety (67).

In summary, blood products are well known for their benefits in relieving a variety of symptoms associated with DES. Many new and emerging blood products are currently being assessed for the presence of key growth factors and their overall effects weighed against their potential risks. Ultimately, as more evidence-based knowledge is obtained on the specific growth factors and their direct impact, patients with ocular defects should be able to receive personalized treatments, better customized to 
their individual needs and pathology, which are becoming the buzzword of all clinical interventions.

\section{AUTHOR CONTRIBUTIONS}

VJD and TB wrote the first draft. CLT made additions. JS reviewed and modified the final draft. All authors approved the final version.

\section{REFERENCES}

1. Schaumberg DA, Dana R, Buring JE, Sullivan DA. Prevalence of dry eye disease among US men: estimates from the physicians' health studies. Arch Ophthalmol (2009) 127(6):763-8. doi:10.1001/archophthalmol.2009.103

2. Barabino S, Labetoulle M, Rolando M, Messmer EM. Understanding symptoms and quality of life in patients with dry eye syndrome. Ocul Surf (2016) 14(3):365-76. doi:10.1016/j.jtos.2016.04.005

3. Shimmura S, Shimazaki J, Tsubota K. Results of a population-based questionnaire on the symptoms and lifestyles associated with dry eye. Cornea (1999) 18(4):408-11. doi:10.1097/00003226-199907000-00003

4. Schaumberg DA, Sullivan DA, Buring JE, Dana MR. Prevalence of dry eye syndrome among US women. Am JOphthalmol (2003) 136(2):318-26. doi:10.1016/S0002-9394(03)00218-6

5. Schein OD, MUÑO B, Tielsch JM, Bandeen-Roche K, West S. Prevalence of dry eye among the elderly. Am J Ophthalmol (1997) 124(6):723-8. doi:10.1016/ S0002-9394(14)71688-5

6. Pflugfelder SC, Solomon A, Stern ME. The diagnosis and management of dry eye: a twenty-five-year review. Cornea (2000) 19(5):644-9. doi:10.1097/ 00003226-200009000-00009

7. Messmer EM. The pathophysiology, diagnosis, and treatment of dry eye disease. Dtsch Arztebl Int (2015) 112(5):71. doi:10.3238/arztebl.2015.0071

8. Nebbioso M, Fameli V, Gharbiya M, Sacchetti M, Zicari AM, Lambiase A. Investigational drugs in dry eye disease. Expert Opin Investig Drugs (2016) 25(12):1437-46. doi:10.1080/13543784.2016.1249564

9. Sullivan BD, Evans JE, Dana MR, Sullivan DA. Influence of aging on the polar and neutral lipid profiles in human meibomian gland secretions. Arch Ophthalmol (2006) 124(9):1286-92. doi:10.1001/archopht.124.9.1286

10. Yoon KC, De Paiva CS, Qi H, Chen Z, Farley WJ, Li DQ, et al. Expression of Th-1 chemokines and chemokine receptors on the ocular surface of C57BL/6 mice: effects of desiccating stress. Invest Ophthalmol Vis Sci (2007) 48(6):2561-9. doi:10.1167/iovs.07-0002

11. Mrugacz M, Ostrowska L, Bryl A, Szulc A, Zelazowska-Rutkowska B, Mrugacz G. Pro-inflammatory cytokines associated with clinical severity of dry eye disease of patients with depression. Adv Med Sci (2017) 62(2):338-44. doi:10.1016/j.advms.2017.03.003

12. Liu R, Gao C, Chen H, Li Y, Jin Y, Qi H. Analysis of Th17-associated cytokines and clinical correlations in patients with dry eye disease. PLoS One (2017) 12(4):e0173301. doi:10.1371/journal.pone.0173301

13. Luo L, Li DQ, Doshi A, Farley W, Corrales RM, Pflugfelder SC. Experimental dry eye stimulates production of inflammatory cytokines and MMP-9 and activates MAPK signaling pathways on the ocular surface. Invest Ophthalmol Vis Sci (2004) 45(12):4293-301. doi:10.1167/iovs.03-1145

14. Tan X, Sun S, Liu Y, Zhu T, Wang K, Ren T, et al. Analysis of Th17-associated cytokines in tears of patients with dry eye syndrome. Eye (Lond) (2014) 28(5):608-13. doi:10.1038/eye.2014.38

15. Miljanović B, Dana R, Sullivan DA, Schaumberg DA. Impact of dry eye syndrome on vision-related quality of life. Am J Ophthalmol (2007) 143(3):40915.e2. doi:10.1016/j.ajo.2006.11.060

16. Ayaki M, Kawashima M, Negishi K, Kishimoto T, Mimura M, Tsubota K. Sleep and mood disorders in dry eye disease and allied irritating ocular diseases. Sci Rep (2016) 6:22480. doi:10.1038/srep22480

17. Zheng $\mathrm{Y}, \mathrm{Wu} \mathrm{X}$, Lin $\mathrm{X}$, Lin $\mathrm{H}$. The prevalence of depression and depressive symptoms among eye disease patients: a systematic review and meta-analysis. Sci Rep (2017) 7:46453. doi:10.1038/srep46453

18. Wan KH, Chen LJ, Young AL. Depression and anxiety in dry eye disease: a systematic review and meta-analysis. Eye (Lond) (2016) 30(12):1558-67. doi:10.1038/eye.2016.186

\section{FUNDING}

This work has been partly supported by an integrated research grant in health and medical sciences from the National Health Research Institute (NHRI), Taiwan (NHRI-EX105-10334EI), and the Ministry of Science and Technology, Taiwan (MOST 106-2628-E-038-001-MY3).

19. Kawashima M, Uchino M, Yokoi N, Uchino Y, Dogru M, Komuro A, et al. Associations between subjective happiness and dry eye disease: a new perspective from the Osaka study. PLoS One (2015) 10(4):e0123299. doi:10.1371/ journal.pone.0123299

20. Mrugacz M, Ostrowska L, Łazarczyk-Kirejczyk J, Bryl A, Mrugacz G, Stefańska E, et al. Dry eye disease in patients treated with antidepressants. Klin Oczna (2013) 115(2):111-4.

21. McDonald M, Patel DA, Keith MS, Snedecor SJ. Economic and humanistic burden of dry eye disease in Europe, North America, and Asia: a systematic literature review. Ocul Surf (2016) 14(2):144-67. doi:10.1016/j.jtos.2015.11.002

22. Yu J, Asche CV, Fairchild CJ. The economic burden of dry eye disease in the United States: a decision tree analysis. Cornea (2011) 30(4):379-87. doi:10.1097/ICO.0b013e3181f7f363

23. Mizuno Y, Yamada M, Shigeyasu C. Annual direct cost of dry eye in Japan. Clin Ophthalmol (2012) 6:755-60. doi:10.2147/OPTH.S30625

24. Clegg JP, Guest JF, Lehman A, Smith AF. The annual cost of dry eye syndrome in France, Germany, Italy, Spain, Sweden and the United Kingdom among patients managed by ophthalmologists. Ophthalmic Epidemiol (2006) 13(4):263-74. doi:10.1080/09286580600801044

25. McMonnies CW. Measurement of symptoms pre- and post-treatment of dry eye syndromes. Optom Vis Sci (2016) 93(11):1431-7. doi:10.1097/OPX. 0000000000000965

26. Pan Q, Angelina A, Zambrano A, Marrone M, Stark WJ, Heflin T, et al. Autologous serum eye drops for dry eye. Cochrane Database Syst Rev (2013) 8:CD009327. doi:10.1002/14651858.CD009327.pub2

27. Pucker AD, Ng SM, Nichols JJ. Over the counter (OTC) artificial tear drops for dry eye syndrome. Cochrane Database Syst Rev (2016) 2:CD009729. doi:10.1002/14651858.CD009729.pub2

28. Simmons PA, Liu H, Carlisle-Wilcox C, Vehige JG. Efficacy and safety of two new formulations of artificial tears in subjects with dry eye disease: a 3-month, multicenter, active-controlled, randomized trial. Clin Ophthalmol (2015) 9:665-75. doi:10.2147/OPTH.S78184

29. Fernandez KB, Epstein SP, Raynor GS, Sheyman AT, Massingale ML, Dentone PG, et al. Modulation of HLA-DR in dry eye patients following 30 days of treatment with a lubricant eyedrop solution. Clin Ophthalmol (2015) 9:1137-45. doi:10.2147/OPTH.S81355

30. Pinto-Bonilla JC, del Olmo-Jimeno A, Llovet-Osuna F, Hernández-Galilea E. A randomized crossover study comparing trehalose/hyaluronate eyedrops and standard treatment: patient satisfaction in the treatment of dry eye syndrome. Ther Clin Risk Manag (2015) 11:595. doi:10.2147/TCRM.S77091

31. Chiambaretta F, Doan S, Labetoulle M, Rocher N, Fekih LE, Messaoud R, et al. A randomized, controlled study of the efficacy and safety of a new eyedrop formulation for moderate to severe dry eye syndrome. Eur J Ophthalmol (2017) 27(1):1-9. doi:10.5301/ejo.5000836

32. Yamada C, King KE, Ness PM. Autologous serum eyedrops: literature review and implications for transfusion medicine specialists. Transfusion (2008) 48(6):1245-55. doi:10.1111/j.1537-2995.2008.01665.x

33. Tsubota K, Higuchi A. Serum application for the treatment of ocular surface disorders. Int Ophthalmol Clin (2000) 40(4):113-22. doi:10.1097/ 00004397-200010000-00009

34. Lopez-Garcia JS, Garcia-Lozano I, Rivas L, Martinez-Garchitorena J. Use of autologous serum in ophthalmic practice. Arch Soc Esp Oftalmol (2007) 82:9-20.

35. Baudouin C, Labbé A, Liang H, Pauly A, Brignole-Baudouin F. Preservatives in eyedrops: the good, the bad and the ugly. Prog Retin Eye Res (2010) 29(4):312-34. doi:10.1016/j.preteyeres.2010.03.001

36. Bhargava R, Kumar P, Phogat H, Kaur A, Kumar M. Oral omega-3 fatty acids treatment in computer vision syndrome related dry eye. Cont Lens Anterior Eye (2015) 38(3):206-10. doi:10.1016/j.clae.2015.01.007 
37. Wang L, Chen X, Hao J, Yang L. Proper balance of omega-3 and omega-6 fatty acid supplements with topical cyclosporine attenuated contact lens-related dry eye syndrome. Inflammopharmacology (2016) 24(6):389-96. doi:10.1007/ s10787-016-0291-2

38. Perez VL, Pflugfelder SC, Zhang S, Shojaei A, Haque R. Lifitegrast, a novel integrin antagonist for treatment of dry eye disease. Ocul Surf (2016) 14(2):207-15. doi:10.1016/j.jtos.2016.01.001

39. Holland EJ, Luchs J, Karpecki PM, Nichols KK, Jackson MA, Sall K, et al. Lifitegrast for the treatment of dry eye disease: results of a phase III, randomized, double-masked, placebo-controlled trial (OPUS-3). Ophthalmology (2017) 124(1):53-60. doi:10.1016/j.ophtha.2016.09.025

40. Bielory BP, Shah SP, O'Brien TP, Perez VL, Bielory L. Emerging therapeutics for ocular surface disease. Curr Opin Allergy Clin Immunol (2016) 16(5):477-86. doi:10.1097/ACI.0000000000000309

41. Tauber J, Karpecki P, Latkany R, Luchs J, Martel J, Sall K, et al. Lifitegrast ophthalmic solution $5.0 \%$ versus placebo for treatment of dry eye disease: results of the randomized phase III OPUS-2 study. Ophthalmology (2015) 122(12):2423-31. doi:10.1016/j.ophtha.2015.08.001

42. Cutolo CA, Barabino S, Bonzano C, Traverso CE. The use of topical corticosteroids for treatment of dry eye syndrome. Ocul Immunol Inflamm (2017):1-10. doi:10.1080/09273948.2017.1341988

43. Tseng CL, Hung YJ, Chen ZY, Fang HW, Chen KH. Synergistic effect of artificial tears containing epigallocatechin gallate and hyaluronic acid for the treatment of rabbits with dry eye syndrome. PLoS One (2016) 11(6):e0157982. doi:10.1371/journal.pone.0157982

44. Wan KH, Chen LJ, Young AL. Efficacy and safety of topical $0.05 \%$ cyclosporine eye drops in the treatment of dry eye syndrome: a systematic review and meta-analysis. Ocul Surf (2015) 13(3):213-25. doi:10.1016/j.jtos.2014.12.006

45. Agarwal P, Rupenthal ID. Modern approaches to the ocular delivery of cyclosporine A. Drug Discov Today (2016) 21(6):977-88. doi:10.1016/j. drudis.2016.04.002

46. Stevenson D, Tauber J, Reis BL. Efficacy and safety of cyclosporin A ophthalmic emulsion in the treatment of moderate-to-severe dry eye disease: a dose-ranging, randomized trial. The cyclosporin A phase 2 study group. Ophthalmology (2000) 107(5):967-74. doi:10.1016/S0161-6420(00)00035-X

47. Wilson SE, Perry HD. Long-term resolution of chronic dry eye symptoms and signs after topical cyclosporine treatment. Ophthalmology (2007) 114(1):76-9. doi:10.1016/j.ophtha.2006.05.077

48. Bourkiza R, Lee V. A review of the complications of lacrimal occlusion with punctal and canalicular plugs. Orbit (2012) 31(2):86-93. doi:10.3109/01676830. 2011.648802

49. Yazdani C, McLaughlin T, Smeeding JE, Walt J. Prevalence of treated dry eye disease in a managed care population. Clin Ther (2001) 23(10):1672-82. doi:10.1016/S0149-2918(01)80136-3

50. Cohen EJ. Punctal occlusion. Arch Ophthalmol (1999) 117(3):389-90. doi:10.1001/archopht.117.3.389

51. Roberts CW, Carniglia PE, Brazzo BG. Comparison of topical cyclosporine, punctal occlusion, and a combination for the treatment of dry eye. Cornea (2007) 26(7):805-9. doi:10.1097/ICO.0b013e318074e460

52. Tong L, Beuerman R, Simonyi S, Hollander DA, Stern ME. Effects of punctal occlusion on clinical signs and symptoms and on tear cytokine levels in patients with dry eye. Ocul Surf (2016) 14(2):233-41. doi:10.1016/j.jtos.2015.12.004

53. Liu D, Sadhan Y. Surgical punctal occlusion: a prospective study. Br J Ophthalmol (2002) 86(9):1031-4. doi:10.1136/bjo.86.9.1031

54. Ervin AM, Law A, Pucker AD. Punctal occlusion for dry eye syndrome. Cochrane Database Syst Rev (2017) 6:CD006775. doi:10.1002/14651858. CD006775.pub3

55. Burnouf T, Goubran HA, Chen TM, Ou KL, El-Ekiaby M, Radosevic M. Blood-derived biomaterials and platelet growth factors in regenerative medicine. Blood Rev (2013) 27(2):77-89. doi:10.1016/j.blre.2013.02.001

56. Burnouf T, Strunk D, Koh MB, Schallmoser K. Human platelet lysate: replacing fetal bovine serum as a gold standard for human cell propagation? Biomaterials (2016) 76:371-87. doi:10.1016/j.biomaterials.2015.10.065

57. Geerling G, Maclennan S, Hartwig D. Autologous serum eye drops for ocular surface disorders. Br J Ophthalmol (2004) 88(11):1467-74. doi:10.1136/bjo. 2004.044347

58. Burnouf T, Chou ML, Wu YW, Su CY, Lee LW. Antimicrobial activity of platelet (PLT)-poor plasma, PLT-rich plasma, PLT gel, and solvent/ detergent-treated PLT lysate biomaterials against wound bacteria. Transfusion (2013) 53(1):138-46. doi:10.1111/j.1537-2995.2012.03668.x

59. Hussain M, Shtein RM, Sugar A, Soong HK, Woodward MA, DeLoss K, et al. Long-term use of autologous serum $50 \%$ eye drops for the treatment of dry eye disease. Cornea (2014) 33(12):1245-51. doi:10.1097/ICO.0000000000000271

60. Anitua E, Muruzabal F, Tayebba A, Riestra A, Perez VL, Merayo-Lloves J, et al. Autologous serum and plasma rich in growth factors in ophthalmology: preclinical and clinical studies. Acta Ophthalmol (2015) 93(8):e605-14. doi:10.1111/aos.12710

61. Klenkler B, Sheardown H, Jones L. Growth factors in the tear film: role in tissue maintenance, wound healing, and ocular pathology. Ocul Surf (2007) 5(3):228-39. doi:10.1016/S1542-0124(12)70613-4

62. Tsubota K, Goto E, Fujita H, Ono M, Inoue H, Saito I, et al. Treatment of dry eye by autologous serum application in Sjögren's syndrome. $\mathrm{Br}$ J Ophthalmol (1999) 83(4):390-5. doi:10.1136/bjo.83.4.390

63. Setten GBV, Tervo T, Tervo K, Tarkkanen A. Epidermal growth factor (EGF) in ocular fluids: presence, origin and therapeutical considerations. Acta Ophthalmol (1992) 202:54-9.

64. Nurden AT. The biology of the platelet with special reference to inflammation, wound healing and immunity. Front Biosci (Landmark Ed) (2018) 23:726-51. doi: $10.2741 / 4613$

65. Nurden AT, Nurden P, Sanchez M, Andia I, Anitua E. Platelets and wound healing. Front Biosci (2008) 13:3532-48.

66. von Hofsten J, Egardt M, Zetterberg M. The use of autologous serum for the treatment of ocular surface disease at a Swedish tertiary referral center. Int Med Case Rep J (2016) 9:47. doi:10.2147/IMCRJ.S97297

67. Marks DC, van der Meer PF; Biomedical Excellence for Safer Transfusion (BEST) Collaborative. Serum eye drops: a survey of international production methods. Vox Sang (2017) 112(4):310-7. doi:10.1111/vox.12502

68. Espinosa A, Hjorth-Hansen H, Aasly K, Teigum I, Sivertsen G, Seghatchian J. Implementation of a standardised method for the production of allogeneic serum eye drops from regular blood donors in a Norwegian University Hospital: some methodological aspects and clinical considerations. Transfus Apher Sci (2015) 53(1):88-91. doi:10.1016/j.transci.2015.05.014

69. Harritshoj LH, Nielsen C, Ullum H, Hansen MB, Julian HO. Ready-made allogeneic $\mathrm{ABO}-$ specific serum eye drops: production from regular male blood donors, clinical routine, safety and efficacy. Acta Ophthalmol (2014) 92(8):783-6. doi:10.1111/aos.12386

70. Badami KG, McKellar M. Allogeneic serum eye drops: time these became the norm? Br J Ophthalmol (2012) 96(8):1151-2. doi:10.1136/ bjophthalmol-2012-301668

71. Cho YK, Huang W, Kim GY, Lim BS. Comparison of autologous serum eye drops with different diluents. Curr Eye Res (2013) 38(1):9-17. doi:10.3109/ 02713683.2012.720340

72. Pan Q, Angelina A, Marrone M, Stark WJ, Akpek EK. Autologous serum eye drops for dry eye. Cochrane Database Syst Rev (2017) 2:CD009327. doi:10.1002/14651858.CD009327.pub3

73. Lopez-Garcia JS, Garcia-Lozano I, Rivas L, Ramirez N, Raposo R, Mendez MT. Autologous serum eye drops diluted with sodium hyaluronate: clinical and experimental comparative study. Acta Ophthalmol (2014) 92(1):e22-9. doi:10.1111/aos.12167

74. WHO. Recommendations for the Production, Quality Control and Regulation of Plasma for Fractionation. Geneva: World Health Organization (2005). Available from: http://www.who.int/biologicals/publications/ECBS\%20 2005\%20Annex\%204\%20Human\%20Plasma\%20Fractionation.pdf

75. WHO. WHO guidelines on good manufacturing practices for blood establishments. WHO Tech Rep Ser (2011) 961:148-214.

76. Burnouf T, Radosevich M. Reducing the risk of infection from plasma products: specific preventative strategies. Blood Rev (2000) 14:94-110. doi:10.1054/ blre.2000.0129

77. Dodd RY. Emerging pathogens and their implications for the blood supply and transfusion transmitted infections. Br J Haematol (2012) 159:135-42. doi:10.1111/bjh.12031

78. Kiely P, Gambhir M, Cheng AC, McQuilten ZK, Seed CR, Wood EM. Emerging infectious diseases and blood safety: modeling the transfusion-transmission risk. Transfus Med Rev (2017) 31(3):154-64. doi:10.1016/j.tmrv.2017.05.002

79. Yawn BP, Wollan PC, St Sauver JL, Butterfield LC. Herpes zoster eye complications: rates and trends. Mayo Clin Proc (2013) 88(6):562-70. doi:10.1016/j. mayocp.2013.03.014 
80. Drew VJ, Barro L, Seghatchian J, Burnouf T. Towards pathogen inactivation of red blood cells and whole blood targeting viral DNA/RNA: design, technologies, and future prospects for developing countries. Blood Transfus (2017) 15(6):512-21. doi:10.2450/2017.0344-16

81. Devine DV, Schubert P. Pathogen inactivation technologies: the advent of pathogen-reduced blood components to reduce blood safety risk. Hematol Oncol Clin North Am (2016) 30(3):609-17. doi:10.1016/j.hoc. 2016.01.005

82. Stahle MU, Brandhorst D, Korsgren O, Knutson F. Pathogen inactivation of human serum facilitates its clinical use for islet cell culture and subsequent transplantation. Cell Transplant (2011) 20(5):775-81. doi:10.3727/0963689 $10 \mathrm{X} 539056$

83. Tseng CL, Chen ZY, Renn TY, Hsiao SH, Burnouf T. Solvent/detergent virally inactivated serum eye drops restore healthy ocular epithelium in a rabbit model of dry-eye syndrome. PLoS One (2016) 11(4):e0153573. doi:10.1371/ journal.pone.0153573

84. Liu L, Hartwig D, Harloff S, Herminghaus P, Wedel T, Geerling G. An optimised protocol for the production of autologous serum eyedrops. Graefes Arch Clin Exp Ophthalmol (2005) 243(7):706-14. doi:10.1007/s00417004-1106-5

85. EDQM. Good Practice Guidelines for Blood Establishments and Hospital Blood Banks Required to Comply with EU Directive 2005/62/EC - Guide to the Preparation, Use and Quality Assurance of Blood Components. Recommendation No. $R$ (95) 15. 18th ed. Strasbourg, France: European Directorate for the Quality of Medicines \& HealthCare (2015).

86. Alio JL, Rodriguez AE, Ferreira-Oliveira R, Wrobel-Dudzinska D, Abdelghany AA. Treatment of dry eye disease with autologous platelet-rich plasma: a prospective, interventional, non-randomized study. Ophthalmol Ther (2017) 6(2):285-93. doi:10.1007/s40123-017-0100-z

87. van der Meer PF, Seghatchian J, Marks DC. Quality standards, safety and efficacy of blood-derived serum eye drops: a review. Transfus Apher Sci (2016) 54(1):164-7. doi:10.1016/j.transci.2016.01.022

88. Chiang C-C, Lin J-M, Chen W-L, Tsai Y-Y. Allogeneic serum eye drops for the treatment of severe dry eye in patients with chronic graft-versus-host disease. Cornea (2007) 26(7):861-3. doi:10.1097/ICO.0b013e3180645cd7

89. Noble BA, Loh RSK, MacLennan S, Pesudovs K, Reynolds A, Bridges LR, et al. Comparison of autologous serum eye drops with conventional therapy in a randomised controlled crossover trial for ocular surface disease. Br J Ophthalmol (2004) 88:647-52. doi:10.1136/bjo.2003.026211

90. Kojima T, Ishida R, Dogru M, Goto E, Matsumoto Y, Kaido M, et al. The effect of autologous serum eyedrops in the treatment of severe dry eye disease: a prospective randomized case-control study. Am J Ophthalmol (2005) 139(2):242-6. doi:10.1016/j.ajo.2004.08.040

91. Jeng BH, Dupps WJ Jr. Autologous serum 50\% eyedrops in the treatment of persistent corneal epithelial defects. Cornea (2009) 28(10):1104-8. doi:10.1097/ICO.0b013e3181a2a7f6

92. Na KS, Kim MS. Allogeneic serum eye drops for the treatment of dry eye patients with chronic graft-versus-host disease. J Ocul Pharmacol Ther (2012) 28(5):479-83. doi:10.1089/jop.2012.0002

93. Celebi AR, Ulusoy C, Mirza GE. The efficacy of autologous serum eye drops for severe dry eye syndrome: a randomized double-blind crossover study. Graefes Arch Clin Exp Ophthalmol (2014) 252(4):619-26. doi:10.1007/s00417014-2599-1
94. Chiang CC, Chen WL, Lin JM, Tsai YY. Allogeneic serum eye drops for the treatment of persistent corneal epithelial defect. Eye (Lond) (2009) 23(2):290-3. doi:10.1038/sj.eye.6703079

95. Higuchi A, Ueno R, Shimmura S, Suematsu M, Dogru M, Tsubota K. Albumin rescues ocular epithelial cells from cell death in dry eye. Curr Eye Res (2007) 32(2):83-8. doi:10.1080/02713680601147690

96. Shimmura S, Ueno R, Matsumoto Y, Goto E, Higuchi A, Shimazaki J, et al. Albumin as a tear supplement in the treatment of severe dry eye. Br J Ophthalmol (2003) 87(10):1279-83. doi:10.1136/bjo.87.10.1279

97. Alio JL, Rodriguez AE, WróbelDudzinska D. Eye platelet-rich plasma in the treatment of ocular surface disorders. Curr Opin Ophthalmol (2015) 26(4):325-32. doi:10.1097/ICU.0000000000000169

98. Alio JL, Arnalich-Montiel F, Rodriguez AE. The role of "eye platelet rich plasma (E-PRP)" for wound healing in ophthalmology. Curr Pharm Biotechnol (2012) 13(7):1257-65. doi:10.2174/138920112800624355

99. Avila MY. Restoration of human lacrimal function following platelet-rich plasma injection. Cornea (2014) 33(1):18-21. doi:10.1097/ICO.0000000000000016

100. Anitua E, de la Fuente M, Riestra A, Merayo-Lloves J, Muruzabal F, Orive G. Preservation of biological activity of plasma and platelet-derived eye drops after their different time and temperature conditions of storage. Cornea (2015) 34(9):1144-8. doi:10.1097/Ico.0000000000000489

101. Lopez-Plandolit S, Morales MC, Freire V, Grau AE, Duran JA. Efficacy of plasma rich in growth factors for the treatment of dry eye. Cornea (2011) 30(12):1312-7. doi:10.1097/ICO.0b013e31820d86d6

102. Anitua E. Plasma rich in growth factors: preliminary results of use in the preparation of future sites for implants. Int J Oral Maxillofac Implants (1999) 14(4):529-35.

103. Seghatchian J, Espinosa A, Burnouf T. Quality, safety and sustained therapeutic efficacy of blood-derived serum eye drops to treat dry eye syndrome: R\&D road map for future progress. Transfus Apher Sci (2016) 54(1):168-9. doi:10.1016/j.transci.2016.01.023

104. Than J, Balal S, Wawrzynski J, Nesaratnam N, Saleh GM, Moore J, et al. Fingerprick autologous blood: a novel treatment for dry eye syndrome. Eye (Lond) (2017) 31(12):1655-63. doi:10.1038/eye.2017.118

105. Tseng CL, Seghatchian J, Burnouf T. Animal models to assess the therapeutic efficacy of human serum and serum-converted platelet lysates for dry eye syndrome: seeing is believing. Transfus Apher Sci (2015) 53(1):95-8. doi:10.1016/j.transci.2015.05.016

106. Chou ML, Wu JW, Gouel F, Jonneaux A, Timmerman K, Renn TY, et al. Tailor-made purified human platelet lysate concentrated in neurotrophins for treatment of Parkinson's disease. Biomaterials (2017) 142:77-89. doi:10.1016/j.biomaterials.2017.07.018

Conflict of Interest Statement: The authors declare that the research was conducted in the absence of any commercial or financial relationships that could be construed as a potential conflict of interest.

Copyright (c) 2018 Drew, Tseng, Seghatchian and Burnouf. This is an open-access article distributed under the terms of the Creative Commons Attribution License (CC BY). The use, distribution or reproduction in other forums is permitted, provided the original author(s) and the copyright owner are credited and that the original publication in this journal is cited, in accordance with accepted academic practice. No use, distribution or reproduction is permitted which does not comply with these terms. 